\title{
Mechanical Properties and Dimensional Stability of Wood-Cement Particleboard from Tree Prunings Residues of Some Wood Species as Affected by The Panel Density
}

\author{
Mohamed A. Abdel-Aal ${ }^{1}$
}

\begin{abstract}
The possibility of using tree prunings residues from four wood species grown in Saudi Arabia to create cementbonded particleboards (CBPs) was studied. The properties of the produced CBPs at different board densities were evaluated. Panels were made using three different board densities $\left(1100,1200\right.$ and $\left.1300 \mathrm{~kg} / \mathrm{m}^{3}\right)$ at a constant $\mathrm{wood} /$ cement ratio ( $1 / 2$ by weight). The mechanical properties and dimensional stability characteristics of the CBP panels were determined. It was found that the tree prunings from the four wood species are suitable raw material to create CBPs after pretreating the particles in either cold or hot water and by using chemical additives. The results indicated that the panels produced from these tree prunings meet the mechanical and dimensional stability requirements of commercial CBP panels. CBP panels with good mechanical properties, good dimensional stability and a high level of board density $(1300 \mathrm{~kg} / \mathrm{m3})$ should be used.
\end{abstract}

Keywords: Board density, cement-bonded particleboard, dimensional stability, mechanical properties, pretreatment, tree prunings, wood species.

\section{INTRODUCTION}

There is a growing wood demand from forest industries because the rapid development of the industry has decreased the wood supply. Many regions around the world have an acute shortage of wood. Saudi Arabia is similar to many developing countries in that there are not adequate forest reserves within the country to satisfy their needs for fuel wood, industrial wood, sawn wood, and wood composite panels. In the wood-based composite panel industry, which includes the manufacture of wood-cement particleboards, efforts are being intensified to determine other suitable wood substitutes. Apart from using tree thinnings, fastgrowing trees and agricultural residues have been attempted (Almeida et al, 2002, Mohamed, 2004, Çöpür et al, 2007).

The cement-bonded particleboard (CBP) is one type of mineral-bonded product that has evolved as a highdensity, smooth board with promising characteristics for exterior use or where fire resistance is required. These panels contain $30-70 \%$ (by weight) of wood particles and $30-60 \%$ of a mineral binder (Vaickelioniene and Vaickelionis, 2006). Wood-wool slabs using magnisite as a binder were first produced; however, later Portland cement was introduced. The most important binder is cement because of its high quality and availability virtually all over the world. CBPs have excellent sound insulation, high resistance to water, termites and fungi, and excellent long-term weather durability in outdoor conditions. CBPs are used in roofing, wall and flooring parts, and noise absorbing partitions.

Many processing factors affect the mechanical properties and dimensional characteristics of CBP panels. The most important factors that affect CBP properties are the wood species and the particle size of the wood. Previous studies have revealed that not all wood species react favourably with cement due to the adverse effects of certain extractives during cement setting. These species are not suitable to manufacture CBPs (Miller and Moslemi, 1991, and Al-Mefarrej and Nasser, 2008; Nasser et al. 2011). Many investigators have performed a series of tests to enhance the compatibility of wood and cement by using different pretreatments and chemical additives. Cold and hot water extraction are among the common pretreatments used to extract the inhibitory substances in wood (Mohamed, 2004, and Olorunnisola, 2008). Calcium chloride is one of the chemical additives that is widely used as an accelerator for cement setting (Fernandez and Taja-on, 2000, and Olorunnisola, 2007). These treatments are relatively inexpensive and simple to use. To overcome the wood shortage and to meet the future demand of wood products, several countries have conducted studies to investigate the use of non-wood materials, agricultural residues, fast-growing trees, lowgrade wood species and/or underused wood species as raw material to create CBPs. Examples of such alternative materials include vine stalks (Nasser et al., 2011), date palm midribs (Nasser and Al-Mefarrej, 2011 and Nasser 2014), arhar stalks (Aggarwal et al., 2008), sisal (Roma et al., 2008), wheat straw

\footnotetext{
${ }^{1}$ Plant Production Department, College of Food and Agricultural Sciences, King Saud University, Riyadh, Saudi Arabia, and

Forestry and Wood Technology Department, Horticulture Research Institute, Agricultural Research Center, Egypt.

Corresponding author: E-mail: moabdelaal@ksu.edu.sa

Received July 8, 2014, Accepted August28, 2014
} 
(Soroushian et al., 2004) and the shell of the babaçu (Almeida et al., 2002). Generally, these studies have shown the viability of using these materials for use in CBP composites. Saudi Arabia is a poor country in terms of timber resources, where tree prunings from trees on the streets and ornamental trees could be an inexpensive and adequate secondary resource.

Athel (Tamarix aphylla) is a forest tree planted throughout Saudia Arabia and is fast-growing, droughtresistant and salt-tolerant. Athel wood is a renewable resource that could be used as necessary raw material for several local uses. In the last three decades, many multi-purpose tree species, i.e., Acacia salicina and Pithecellobium dulce, were imported into the country and planted as fast-growing tree species to produce biomass (Aref et al., 2003). These trees are used to supplement fuel wood and fibrous raw materials. The suitability of these tree prunings as raw material for CBP manufacturing has not yet been explored. There is no accurate estimate in Saudi Arabia regarding the wastes accumulated from pruning Ficus altissima trees. However, annually, there are huge quantities of biomass due to seasonal pruning of this wood species as a regular agricultural practice in public gardens and streets. Most of these residues in developing countries are plowed into the soil or burned in fields; however, in developed countries, the residues are used to manufacture different types of wood products, i.e., pulp and paper (Abdel-Aal, 2013, Al Mefarrej et al. 2013), particleboards and fibreboards (Nasser 2012 and Hegazy and Aref, 2010). El-Juhany et al. (2003) stated that most of the tree prunings in Saudi Arabia are eliminated by incineration or discarded as waste by costly conventional methods, which can be considered as environmental pollution.

The objectives of this study were to investigate the effects of wood species and board target density on the properties of CBP panels from tree prunings from four hardwood species grown throughout Saudi Arabia.

\section{MATERIALS AND METHODS}

\section{Raw materials}

Tree prunings residues of four different tree species growing in Riyadh city were collected during 2011 and used as lignocellulosic raw materials to manufacture wood-cement particleboards (WCPs). The species were Acacia salicina, Ficus altissima, Pithecellobium dulce and Tamarix aphylla. The characteristics of these species are listed in Table 1. After being collected and air-dried, the woody materials were cut into small pieces or discs using a band saw and fed through a laboratory hammer mill using a 5-mm screen. Two particle sizes were used in the current study: particles that were passed through a $0.8-\mathrm{mm}$ sieve and retained on a $0.4-\mathrm{mm}$ sieve $(-20 /+40$ mesh $)$ were used to manufacture WCP panels. Particles that were passed through $0.4-\mathrm{mm}$ sieve and retained on a $0.27-\mathrm{mm}$ sieve $(-40 /+60$ mesh) were used to perform the chemical analysis of the wood. The wood particles $(-20 /+40$ mesh) were pretreated by either cold water soaking or hot water extraction before manufacturing the WCP panels according to Nasser (1996) and Moslemi et al. (1983).

Commercial Portland cement (Type I), which met the ASTM specification (ASTM C150, 1984) and was manufactured by Yamama Saudi Cement Company Limited, Riyadh Saudi Arabia, was used in this study as a binder. A list of several of its chemical composition is shown in Table 2 as provided by the supplier.

\section{Chemical Analysis of the Woody Materials}

The percentages of the woody extractives based on the oven-dried weight was determined according to ASTM D1105 (1989). The contents of the three primary chemical components of wood i.e., cellulose, hemicelluloses, and lignin, were then determined using extractive-free wood meal and based on the oven-dried weight according to the standard methods described in the ASTM designations (ASTM, 1989) D1103, D1104 and D1106, respectively. In addition, the ash content was determined according to ASTM-D1 102 (1989).

Table 1. Characteristics of the pruning residues of the four wood species

\begin{tabular}{lccccc}
\hline \multicolumn{1}{c}{ Wood Species } & Height $(\mathbf{m})$ & Diameter $(\mathbf{c m})$ & Age (year) & SG & MC* $(\%)$ \\
\hline Acacia salicina & 9.65 & 13.5 & $10-12$ & 0.561 & 8.45 \\
\hline Ficus altissima & 19.3 & 26.5 & $20-25$ & 0.460 & 9.65 \\
\hline Pithecellobium dulce & 12.8 & 14.3 & $10-12$ & 0.532 & 8.79 \\
\hline Tamarix aphylla & 32.2 & 35.7 & $30-35$ & 0.600 & 15.16 \\
\hline
\end{tabular}

Each value is an average of 3 trees.

$\mathrm{SG}$ is the basic specific gravity, and MC is the moisture content. Each value is an average of 10 samples.

* After being air-dried and before processing. Date palm required additional drying to decrease the MC. 
Table 2. Properties of ordinary Portland cement (Type I).

\begin{tabular}{|c|c|c|c|c|c|c|c|c|c|}
\hline & \multicolumn{6}{|c|}{ Chemical composition (\%) } & \multicolumn{2}{|c|}{ Setting time (min) } & $\mathrm{C}_{\max }$ \\
\hline & $\mathrm{SiO}_{2}$ & $\mathbf{A l}_{2} \mathbf{O}_{3}$ & $\mathrm{Fe}_{2} \mathrm{O}_{3}$ & $\mathrm{CaO}$ & MgO & $\mathrm{SO}_{3}$ & Initial & Final & (MPa) \\
\hline Cementused & 20.46 & 5.69 & 3.88 & 64.82 & 0.72 & 2.55 & 105 & 165 & 29.9 \\
\hline ASTM* $^{*}$ & $(-)$ & $(-)$ & $(-)$ & $(-)$ & Max 6.0 & Max 3.5 & Min. 45 & Max. 375 & Min. 19.7 \\
\hline
\end{tabular}

Reported by the supplier (Yamama Saudi Cement Company Limited).

(-) limit is not specified.

Time of setting was performed by the Vicat test method.

$\mathrm{C}_{\max }$ is the compressive strength of cement after 7 days.

According to standard specification for Portland cement (ASTM C150, 1997).

\section{Hydration test}

Twelve treatments were performed for each species: every combination between pre-treatment (untreated, cold water and hot water) and the addition of four different chemicals (none, $\mathrm{CaCl}_{2}, \mathrm{Al}_{2}\left(\mathrm{SO}_{4}\right)_{3}$ or $\mathrm{MgCl}_{2}$ ) was tested. Hydration data was obtained, and the inhibitory index was calculated according to Moslemi et al. (1983). Wood materials mitigate the temperature increase that occurs during the setting process of cement.

\section{Treatment selection for WCP manufacturing}

The hydration data (not included) revealed that the four wood species cannot be used directly as raw materials for WCPs. The wood species must first be pre-treated by either cold or hot water with an addition of $3 \mathrm{wt} \% \mathrm{CaCl}_{2}$ or $\mathrm{MgCl}_{2}$. As seen in Table 3, the best treatment differed depending on the wood species. Using the best treatment, the four wood species were all suitable for WCP production according to Sandermann and Kohler (1964) and Hachmi et al. (1990). The results showed that the time to reach the maximum temperature $\left(\mathrm{t}_{\max }\right)$ ranged from 2.5 to $4.0 \mathrm{~h}$; therefore, the panels were pressed in an automatic hydraulic press for at least $4 \mathrm{~h}$ and then clamped for $20 \mathrm{~h}$ before being removed from the mould. These results agree with the results from previously published reports (Olorunnisola, 2007).

\section{WCP panels preparation}

The WCP panels were manufactured based on the results of the hydration test (Table 3) using the best treatment, which included a pre-treatment (cold or hot water) and the addition of chemical additives $\left(\mathrm{CaCl}_{2}\right.$ or $\left.\mathrm{MgCl}_{2}\right)$ based on the method described by Papadopoulos (2008). Oven-dried wood particles (278 $\mathrm{g})$ and an aqueous solution (24.3 $\mathrm{g}$ of chemical additives dissolved in $383.4 \mathrm{~mL}$ of distilled water) were hand-mixed. Then, $810 \mathrm{~g}$ of Portland cement (Type I) was added to the wetted particles, and the constituents were thoroughly mixed until the cement paste was completely hydrated. The distilled water quantity was calculated according to the relationship developed by Simatupang (1979). After approximately 15 minutes of hand mixing, an open-top box made of composite wood and coated with a phenolic layer, which had an inside base with dimensions of $30 \times 30 \mathrm{~cm}$ and a height of 3.1 $\mathrm{cm}$, was used to form the panel. The mat was then coldpressed using a hydraulic press (Carver Monarch) to a $10-\mathrm{mm}$ thickness, and the panel remained under a constant pressure for $20 \mathrm{~h}$ using a press clamp. The panels were carefully extracted from the mould, misted with water, wrapped in cellophane and aligned before conditioning at room temperature and relative humidity for at least 1 month. In total, 36 panels were manufactured, which represented four wood species, three target densities and three panels per combination.

\section{Test specimens preparation}

The CBP panels were dried at approximately $70{ }^{\circ} \mathrm{C}$ for $8 \mathrm{~h}$ after conditioning and before cutting. All the CBP panels were trimmed by cutting approximately 1 $\mathrm{cm}$ from each side to the dimensions of 28 by $28 \mathrm{~cm}$.

Table 3. Hydration parameters for the best treatments selected to manufacture WCP panels.

\begin{tabular}{lccccccc}
\hline & \multicolumn{2}{c}{ Best treatment } & \multicolumn{4}{c}{ Hydration data and indices } \\
\hline $\begin{array}{c}\text { Wood } \\
\text { Species }\end{array}$ & $\begin{array}{c}\text { Pre- } \\
\text { treatment }\end{array}$ & $\begin{array}{c}\text { Chemical } \\
\text { additive }\end{array}$ & $\begin{array}{c}\mathbf{T}_{\max } \\
\left.\mathbf{(}^{\mathbf{0}} \mathbf{C}\right)\end{array}$ & $\begin{array}{c}\Delta \mathbf{T} \\
\left.\mathbf{(}^{\mathbf{0}} \mathbf{C}\right)\end{array}$ & $\begin{array}{c}\mathbf{t}_{\mathbf{m a x}} \\
(\mathbf{h r s})\end{array}$ & $\begin{array}{c}\mathbf{I} \\
\mathbf{C}_{\mathbf{A}} \\
\mathbf{( \% )}\end{array}$ \\
\hline A. salicina & $\mathrm{CWE}$ & $\mathrm{CaCl}_{2}$ & $74.53^{\mathrm{C}}$ & $51.03^{\mathrm{C}}$ & $3.00^{\mathrm{C}}$ & $-0.81^{\mathrm{B}}$ & $84.51^{\mathrm{B}}$ \\
\hline F. altissima & $\mathrm{HWE}$ & $\mathrm{MgCl}_{2}$ & $72.66^{\mathrm{D}}$ & $49.00^{\mathrm{C}}$ & $4.00^{\mathrm{A}}$ & $-0.45^{\mathrm{B}}$ & $81.75^{\mathrm{C}}$ \\
\hline$P$. dulce & $\mathrm{HWE}$ & $\mathrm{MgCl}_{2}$ & $76.80^{\mathrm{B}}$ & $53.03^{\mathrm{B}}$ & $3.50^{\mathrm{B}}$ & $-0.68^{\mathrm{B}}$ & $85.13^{\mathrm{B}}$ \\
\hline$T$. aphylla & $\mathrm{HWE}$ & $\mathrm{CaCl}_{2}$ & $80.20^{\mathrm{A}}$ & $57.93^{\mathrm{A}}$ & $2.50^{\mathrm{D}}$ & $0.79^{\mathrm{A}}$ & $89.81^{\mathrm{A}}$ \\
\hline Net cement & - & - & 88.60 & 65.6 & 6.25 & 0 & 100 \\
\hline
\end{tabular}

CWE: cold water extraction, HWE: hot water extraction.

$\mathrm{T}_{\max }$ : maximum temperature, $\Delta \mathrm{T}$ : temperature increase above room temperature, 
$\mathrm{t}_{\max }$ : time to reach $\mathrm{T}_{\max }$, I: inhibitory index and $\mathrm{C}_{\mathrm{A}}$ : compatibility factor.

Test specimens were prepared and cut to determine the mechanical properties of the CBP panels and the dimensional stability properties according to ASTM D1037 (1989). Two samples for the bending test, three specimens for the IB test and three specimens for the dimensional stability test were cut from each panel.

\section{Mechanical properties of the WCP panels}

In accordance with ASTM D-1037 (1989) with several modifications due to the limited size of the panels and by using an Instron Testing Machine (Model 3382), static bending, internal bond, screw withdrawal and Janka hardness tests were performed on the WCP panels. The modulus of rupture, modulus of elasticity, internal bond strength, screw holding power and Janka hardness number were calculated and recorded. After static bending was completed, the specimens were cut near the failure zone to determine the density and moisture content of the WCPs by the displacement method in water and the conventional dry method, respectively.

\section{Dimensional stability characteristics}

Dimensional stability characteristics, which include water uptake (WU), thickness swelling (TS) and linear expansion (LE) of the CBP panels, were determined according to ASTM D-1037, 1989. The samples were soaked in a water bath at room temperature for $2 \mathrm{~h}$ and then taken out and weighed. The samples were then reimmersed to complete the 24-h soaking time. The percentage of WU, TS and LE after $24 \mathrm{~h}$ were expressed based on the original state.

\section{Statistical analysis}

A randomised complete design (CRD) with two factors was used to study the differences in the properties of the CBP panels using the analysis of variance (ANOVA). Using the SAS statistical package (2004), the mean values were tested by an LSD test $(p<0.05)$ to detect the significance of the differences between the four species and the different panel target densities of the CBP panels.

\section{RESULTS AND DISCUSSIONS}

\section{Chemical analysis of the four wood species}

The chemical composition of the wood is one of the most important factors that affect the compatibility between wood and cement and the mechanical properties of the produced WCP panels. A comparison of the chemical composition between the four wood species and hardwood is presented in Table 4. There were significant differences for all chemical constituents. These variations might explain the differences between the produced WCPs. It was evident that, with the exception of the extractives content of $T$. aphylla and the ash content of all the wood species, all chemical constituents fell within the range of hardwood species. The high extractive content and the solubility in cold and hot water of T. aphylla may be attributed to the inclusion of bark in the wood meal (Table 1). The last two parameters are the most important factors that influence the compatibility between wood and cement (Moslemi et al., 1983). The pre-treatment of the wood particles most likely removed many extraneous substances that inhibit cement setting, which resulted in a stronger bond between the wood particles and the cement and improved the mechanical properties of the produced WCP panels (Moslemi et al. 1983; Nasser 1996; Pehanich et al. 2004; Nasser et al. 2011). However, in the current work, these components may have had a smaller effect on the properties of the WCP panels because the wood particles were pre-treated by either cold or hot water before manufacturing the panels. The ash content of the wood species appears to be extremely high compared with that of hardwood species and ranged from $1.0 \%$ for $A$. salicina to $6.4 \%$ for T. aphylla (Table 5). Generally, it is known that the ash content of wood is less than 1\%; however, many researchers (Al-Mefarrej et al. 2011; Abdel-Aal et al. 2011) have reported that most wood species grown in Saudi Arabia have a higher ash content, greater than $2 \%$.

\section{Effect of wood species on the CBP panel properties}

The mean values and standard deviations of the physical and mechanical properties and the dimensional stability characteristics of the CBP panels are presented in Table 5. The analysis of variance showed that all the CBP panel properties, with the exception of the physical properties (moisture content and density), differed among the four wood species. This result indicates that the type of wood species significantly affects the properties of the produced CBP panels. It is clear that $A$. salicina and $P$. dulce exhibited the highest MOR value, and T. aphylla exhibited the lowest MOR value.

As shown in Table 5 and Fig. 1, the MOR and MOE values for all of the CBP panels met the minimum requirements set by the International Organisation for Standardisation (ISO 8335-1987), and these values compare favourably to $\mathrm{CBP}$ data published in past studies. The MOR values of the CBP panels made from the coconut shell of babaçu were between 1.6 and 3.8 $\mathrm{N} / \mathrm{mm}^{2}$, and the MOE values were between 821 to 2650 $\mathrm{N} / \mathrm{mm}^{2}$ (Almeida et al. 2002). The IB values ranged from 1.3 to $1.5 \mathrm{~N} / \mathrm{mm}^{2}$ and exceeded, by at least three 
fold, the requirement set forth by the ISO standard $(0.45$

$\mathrm{N} / \mathrm{mm}^{2}$ ).

Table 4. Chemical analysis of the four wood species used to manufacture the WCP panels.

\begin{tabular}{|c|c|c|c|c|c|}
\hline \multirow[b]{2}{*}{ Wood species } & \multicolumn{5}{|c|}{ Percentage content of } \\
\hline & Extractives* & Holocellulose & Lignin & Ash & CWS \\
\hline A. salicina & $5.2^{\mathrm{C}}$ & $68.3^{\mathrm{B}}$ & $31.7^{\mathrm{B}}$ & $1.0^{\mathrm{D}}$ & $3.9^{\mathrm{D}}$ \\
\hline F. altissima & $9.9^{\mathrm{B}}$ & $69.7^{\mathrm{AB}}$ & $30.4^{\mathrm{BC}}$ & $3.0^{\mathrm{C}}$ & $9.2^{\mathrm{B}}$ \\
\hline P. dulce & $6.1^{\mathrm{C}}$ & $70.6^{\mathrm{A}}$ & $29.4^{\mathrm{C}}$ & $4.8^{\mathrm{B}}$ & $5.7^{\mathrm{C}}$ \\
\hline T. aphylla & $16.3^{\mathrm{A}}$ & $66.4^{\mathrm{C}}$ & $33.6^{\mathrm{A}}$ & $6.4^{\mathrm{A}}$ & $12.7^{\mathrm{A}}$ \\
\hline Hardwood $^{+}$ & $2-8$ & $60-85$ & $23-30$ & $0.2-0.5$ & $4-6$ \\
\hline
\end{tabular}

Each value is an average of 5 samples.

* Total extractives by ASTM D1105 (1989).

Means with the same letter in a column are not significantly different at a 0.05 probability level according to the LSD test.

+ Fengel and Wegener (1987).

CWS: cold water solubles.

Table 5. Mean values* and standard deviations of the mechanical and dimensional stability properties of the WCP panels made from the four wood species

\begin{tabular}{|c|c|c|c|c|c|c|}
\hline & \multicolumn{3}{|c|}{ Mechanical properties } & \multicolumn{3}{|c|}{ Dimensional stability (\%) } \\
\hline & MOE & IB & SHP & Water & Thickness & Linear \\
\hline Wood species & $\left(\mathrm{N} / \mathrm{mm}^{2}\right)$ & $\left(\mathrm{N} / \mathrm{mm}^{2}\right)$ & $(\mathrm{N})$ & uptake & swelling & expansion \\
\hline \multirow[t]{2}{*}{ A. salicina } & $4850^{\mathrm{B}}$ & $1.45^{\mathrm{A}}$ & $1601^{\mathrm{A}}$ & $14.93^{\mathrm{C}}$ & $1.00^{\mathrm{B}}$ & $0.53^{\mathrm{C}}$ \\
\hline & $(1600)$ & $(0.4)$ & $(312)$ & $(5.2)$ & $(0.2)$ & $(0.2)$ \\
\hline \multirow[t]{2}{*}{ F. altissima } & $4740^{\mathrm{B}}$ & $1.32^{\mathrm{B}}$ & $1201^{\mathrm{C}}$ & $19.09^{\mathrm{B}}$ & $1.29^{\mathrm{A}}$ & $0.72^{\mathrm{A}}$ \\
\hline & $(800)$ & $(0.9)$ & $(430)$ & $(7.7)$ & $(0.6)$ & $(0.3)$ \\
\hline \multirow[t]{2}{*}{ P. dulce } & $6130^{\mathrm{A}}$ & $1.28^{\mathrm{B}}$ & $1290^{\mathrm{B}}$ & $18.13^{\mathrm{B}}$ & $0.68^{\mathrm{C}}$ & $0.34^{\mathrm{D}}$ \\
\hline & $(900)$ & $(0.2)$ & $(187)$ & $(4.3)$ & $(0.3)$ & $(0.1)$ \\
\hline \multirow[t]{2}{*}{ T. aphylla } & $6350^{\mathrm{A}}$ & $1.32^{\mathrm{B}}$ & $1228^{\mathrm{BC}}$ & $23.28^{\mathrm{A}}$ & $1.21^{\mathrm{A}}$ & $0.60^{\mathrm{B}}$ \\
\hline & $(700)$ & $(0.3)$ & $(196)$ & $(5.3)$ & $(0.3)$ & $(0.1)$ \\
\hline Requirement & 3000 & 0.45 & & - & 8 & \\
\hline
\end{tabular}

* Each value is an average of 27 specimens.

() Values between parentheses are standard deviations.

Means with the same letter in a column are not significantly different at a 0.05 probability level according to the LSD test.

MOE: modulus of elasticity, IB: internal bond, SHP: screw holding power.

Dimensional stability was performed after being soaked in water for $24 \mathrm{~h}$.

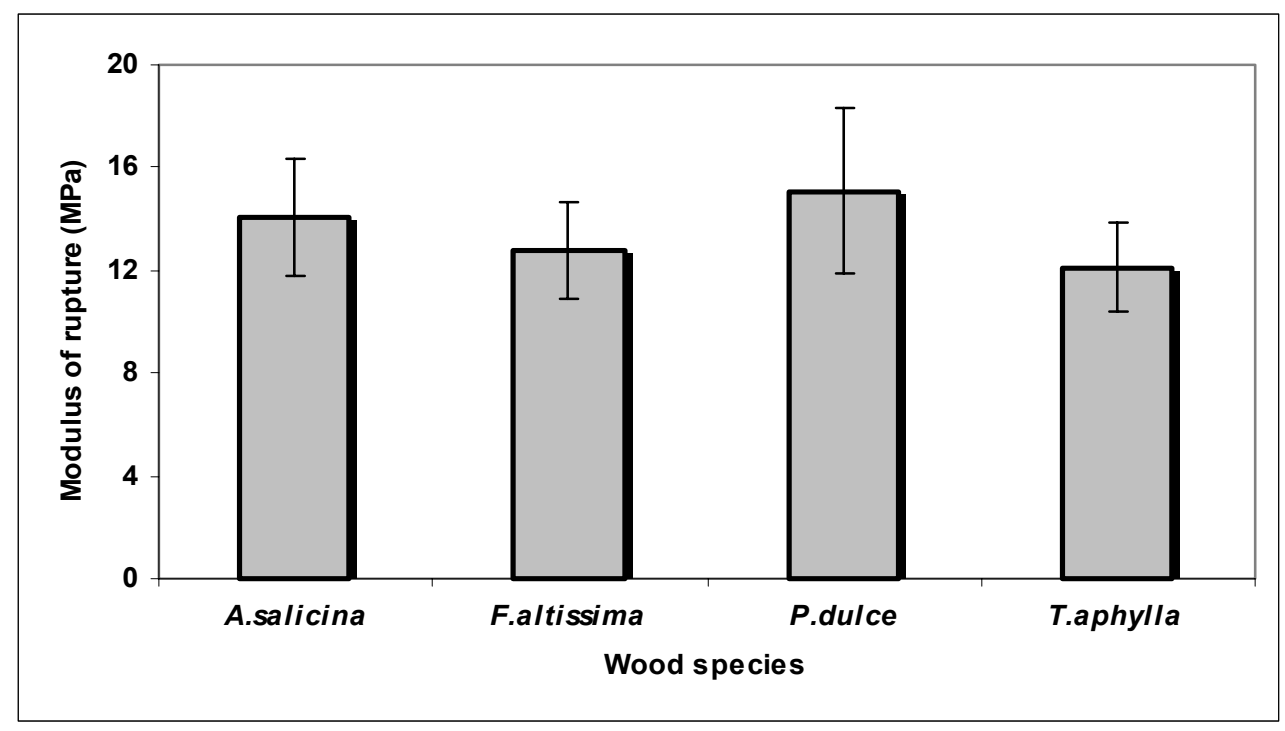




\section{Fig. 1. Modulus of rupture of CBP panels made from the four wood species}

These results may be attributed to the use of pretreated wood particles in manufacturing the CBP panels, which improved the compatibility between the wood particles and the cement. Many researchers have concluded that the water-soluble extractives of wood could potentially inhibit the normal setting and strength development of cement (Olorunnisola, 2007 and Ashori et al., 2011). Researchers have reported IB values between 0.4 and $1.3 \mathrm{~N} / \mathrm{mm}^{2}$ for a wood-wool cement board made from eucalyptus and poplar.

The results indicate that the lowest water absorption, which was judged based on the 24-h water immersion (WA) values, was observed in panels made from $A$. salicina $(14.9 \%)$. The CBP panels made from $\mathrm{T}$. aphylla had the highest water uptake value $(23.3 \%)$. The thickness swelling values after the 24-h water immersion ranged from $0.7 \%(P$. dulce $)$ to $1.3 \%(F$. altissima). These values are well below the maximum limit set by the ISO standard (8.0\%). The CBP panels made from the four wood species exhibited a greater dimensional stability compared with previously reported data.

The mechanical properties of the CBP panels made in this study were superior to those of other cementbonded composites using different raw materials under different manufacturing variables (Almedia et al. 2002; Sudin and Ibrahim 2001; Semple et al. 2002; Ashori et al. 2011). All of the physical and mechanical properties of the CBP panels made from the four wood species surpassed the minimum requirements; the dimensional stability characteristics of the panels were also lower than the maximum limits of particleboard standards. These results agree with (Okino et al., 2004; Olorunnisola, 2007; Aggarwal et al., 2008;

Table 6. The effect of the target density of the CBP panels on the mechanical and dimensional stability of the WCP panels.

\begin{tabular}{lcccccc}
\hline & \multicolumn{2}{c}{ Mechanical properties } & \multicolumn{3}{c}{ Dimensional stability (\%) } \\
\hline Board & MOR & MOE & JHN & Water & Thickness & Linear \\
\hline Density & $\left(\mathbf{N} / \mathbf{m m}^{2}\right)$ & $\left(\mathbf{N} / \mathbf{m m}^{2}\right)$ & $\mathbf{( N )}$ & uptake & swelling & expansion \\
\hline 1100 & $10.33^{\mathrm{C}}$ & $4730^{\mathrm{B}}$ & $4006^{\mathrm{C}}$ & $19.56^{\mathrm{A}}$ & $1.20^{\mathrm{A}}$ & $0.63^{\mathrm{A}}$ \\
& $(0.8)$ & $(1100)$ & $(1099)$ & $(7.3)$ & $(0.6)$ & $(0.3)$ \\
\hline 1200 & $13.78^{\mathrm{B}}$ & $5530^{\mathrm{AB}}$ & $5142^{\mathrm{B}}$ & $19.65^{\mathrm{A}}$ & $1.06^{\mathrm{AB}}$ & $0.53^{\mathrm{B}}$ \\
& $(2.8)$ & $(1700)$ & $(703)$ & $(4.2)$ & $(0.3)$ & $(0.2)$ \\
\hline 1300 & $16.44^{\mathrm{A}}$ & $6300^{\mathrm{A}}$ & $5731^{\mathrm{A}}$ & $15.96^{\mathrm{B}}$ & $0.87^{\mathrm{B}}$ & $0.48^{\mathrm{B}}$ \\
& $(2.7)$ & $(1000)$ & $(852)$ & $(6.4)$ & $(0.3)$ & $(0.2)$ \\
\hline Requirement & Min 9.00 & min 3000 & & - & max 8.0 & \\
\hline
\end{tabular}

Each value is an average of 36 specimens.

() Values between parentheses are standard deviations.

Mean values with the same letter in a column are not significantly different at a 0.05 probability level according to the LSD test.

MOR: modulus of rupture, MOE: modulus of elasticity, JHN: Janka hardness number.

Dimensional stability was performed after being immersed in water for $24 \mathrm{~h}$.
Papadopoulos, 2008; Nasser 2014). According to these results, CBP panels can be made from the tree prunings of the four studied wood species after pre-treating the particles with either cold water soaking or hot water extraction and adding either calcium chloride or magnesium chloride as an accelerator.

\section{Effect of board density on the properties of CBP panels} the target board density of the CBP panels on their properties was significant, with the exception of oisture content. The effect of the target board density mean values of the physical and mechanical properties of the CBP panels are presented in Table 6 and Fig. 2. The results indicated that the mechanical properties of the CBP panels increased as the board thickness swelling and linear expansion of the CBP panels; these values decreased as the board density increased. These results agree with the results from (Papadopoulos 2008 and Nasser 2014).

Effect of the interaction between wood species and board density on the CBP properties

The interaction between wood species and board density of the CBP panels was highly significant for all mechanical properties and dimensional stability characteristics, with the exception of moisture content, which was not significant. The mean values and standard deviations of the CBP panel properties made from the four wood species at the three target board densities are presented in Table 7 and Figs. 4-6.
The analysis of variance indicated that the effect of 


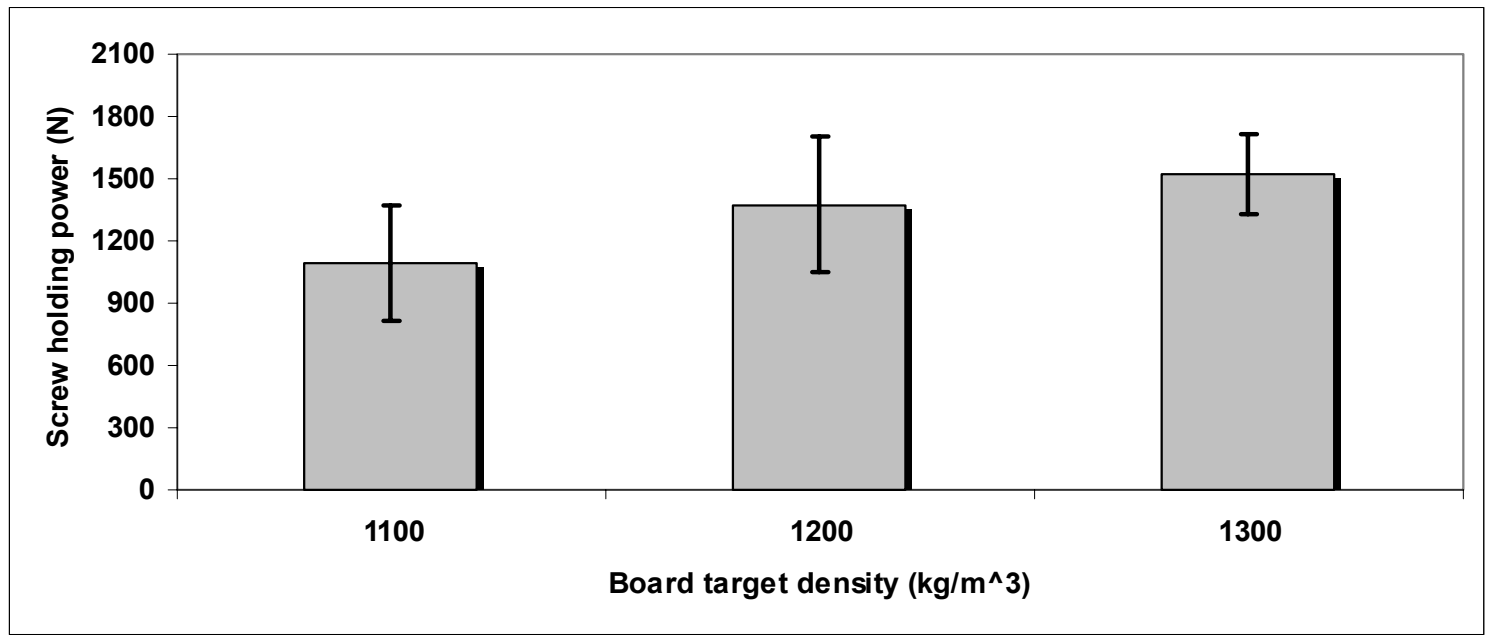

Fig. 2. Effects of board density on the screw holding power of the CBP panels

Table 7. Properties of the WCP panels of the four wood species under the target density of the panels

\begin{tabular}{|c|c|c|c|c|c|c|}
\hline \multirow[b]{2}{*}{ Wood species } & \multirow[b]{2}{*}{$\begin{array}{c}\text { Board } \\
\text { density } \\
\left(\mathrm{kg} / \mathrm{m}^{3}\right) \\
\end{array}$} & \multicolumn{3}{|c|}{ Mechanical properties } & \multicolumn{2}{|c|}{ Dimensional stability } \\
\hline & & $\begin{array}{c}\text { Modulus of } \\
\text { rupture } \\
\left(\mathrm{N} / \mathbf{m m}^{2}\right) \\
\end{array}$ & $\begin{array}{l}\text { Screw } \\
\text { holding } \\
(\mathrm{N}) \\
\end{array}$ & $\begin{array}{c}\text { Janka } \\
\text { hardness } \\
(\mathbf{N}) \\
\end{array}$ & $\begin{array}{c}\text { Thickness } \\
\text { swelling } \\
(\%) \\
\end{array}$ & $\begin{array}{c}\text { Linear } \\
\text { expansion } \\
(\%) \\
\end{array}$ \\
\hline \multirow[t]{3}{*}{ A. salicina } & 1100 & $11.0 \pm 0.8$ & $1433 \pm 129$ & $4098 \pm 927$ & 1.03 & 0.73 \\
\hline & 1200 & $16.7 \pm 3.1$ & $1988 \pm 117$ & $5227 \pm 610$ & 0.81 & 0.47 \\
\hline & 1300 & $14.5 \pm 2.0$ & $1381 \pm 141$ & $5878 \pm 976$ & 1.15 & 0.39 \\
\hline \multirow[t]{3}{*}{ F. altissima } & 1100 & $9.8 \pm 0.6$ & $738 \pm 86$ & $4144 \pm 799$ & 1.89 & 1.05 \\
\hline & 1200 & $13.0 \pm 0.2$ & $1143 \pm 32$ & $4795 \pm 966$ & 1.45 & 0.77 \\
\hline & 1300 & $15.7 \pm 2.6$ & $1720 \pm 47$ & $5948 \pm 707$ & 0.53 & 0.34 \\
\hline \multirow[t]{3}{*}{ P. dulce } & 1100 & $10.7 \pm 0.7$ & $1111 \pm 53$ & $4634 \pm 511$ & 0.51 & 0.25 \\
\hline & 1200 & $14.4 \pm 1.9$ & $1248 \pm 47$ & $5853 \pm 311$ & 1.01 & 0.28 \\
\hline & 1300 & $20.1 \pm 0.9$ & $1511 \pm 110$ & $6454 \pm 247$ & 0.52 & 0.49 \\
\hline \multirow[t]{3}{*}{ T. aphylla } & 1100 & $9.8 \pm 0.5$ & $1090 \pm 68$ & $3147 \pm 335$ & 1.38 & 0.49 \\
\hline & 1200 & $11.1 \pm 0.9$ & $1118 \pm 74$ & $4694 \pm 256$ & 0.97 & 0.62 \\
\hline & 1300 & $15.5 \pm 0.8$ & $1476 \pm 70$ & $4642 \pm 199$ & 1.29 & 0.69 \\
\hline $\mathrm{LSD}_{0.05}$ & & 2.8 & 148 & 1074 & 0.29 & 0.26 \\
\hline
\end{tabular}

Each value is an average of 9 specimens \pm standard deviations.

Dimensional stability was performed after being immersed in water for $24 \mathrm{~h}$.

$\mathrm{LSD}_{0.05}$ for the interaction between the species and board density.

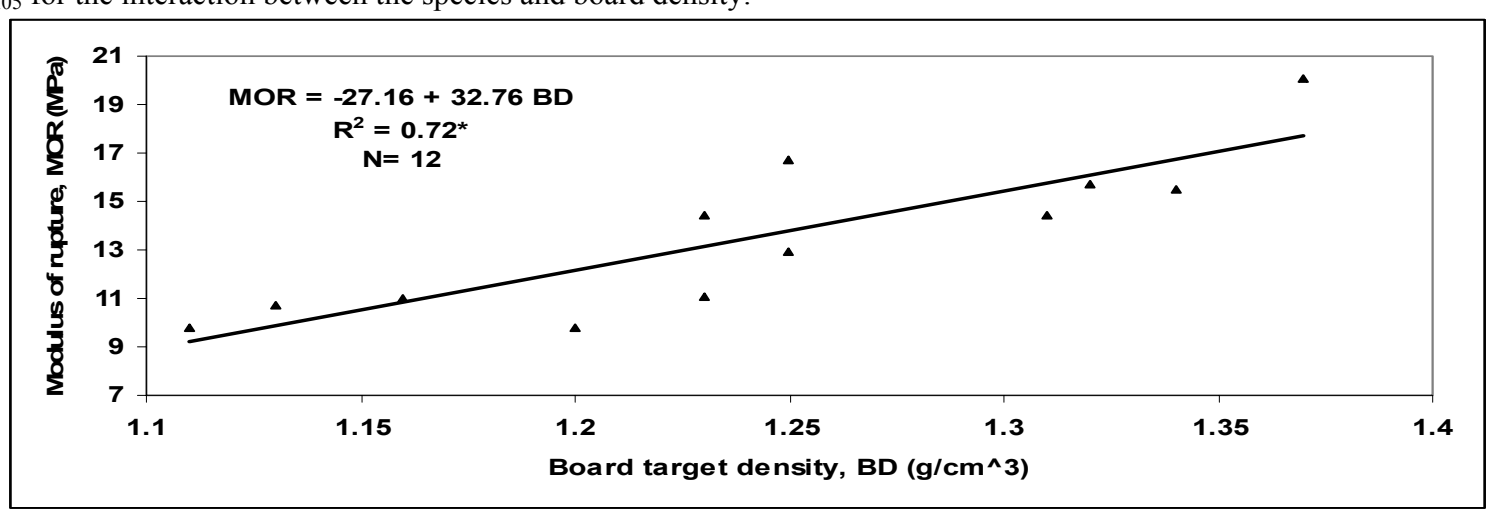

Fig. 3. Relationship between MOR and the density (oven-dry bases) of the WCP panels 


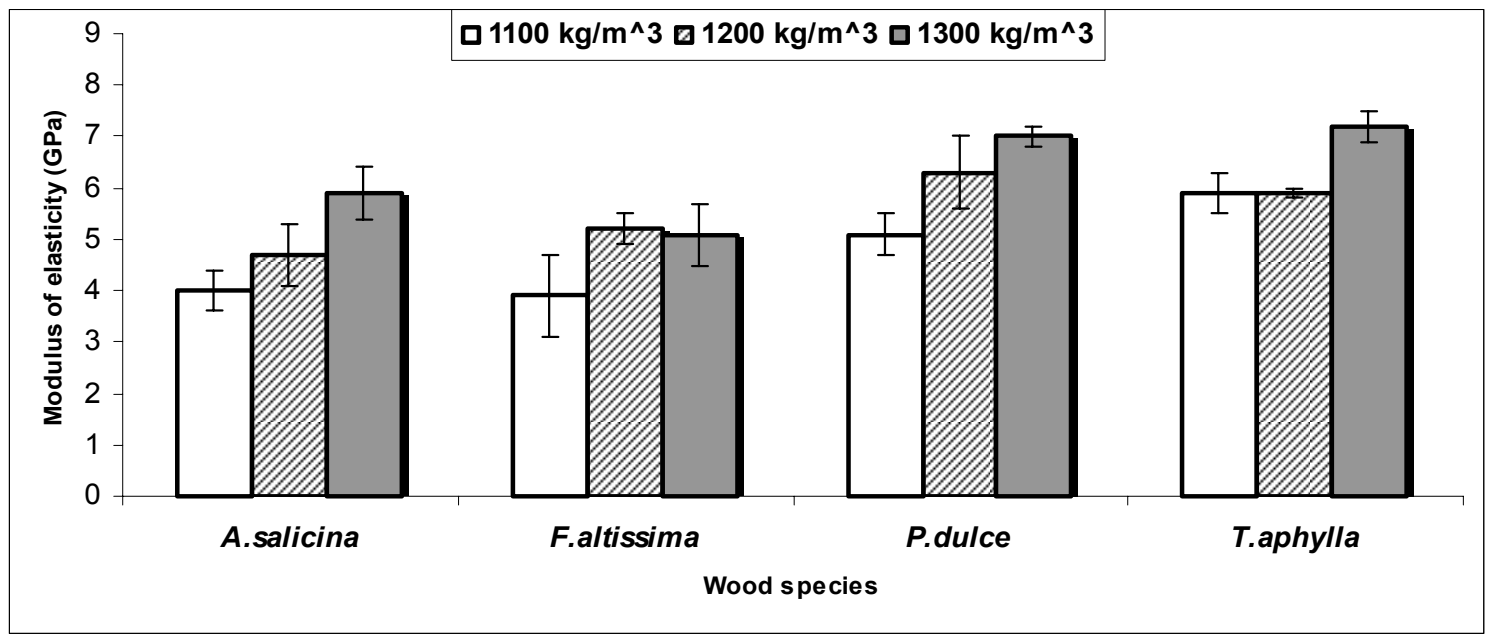

Fig. 4. Effect of the board density of the panels on the MOE of the WCP panels from the four wood species

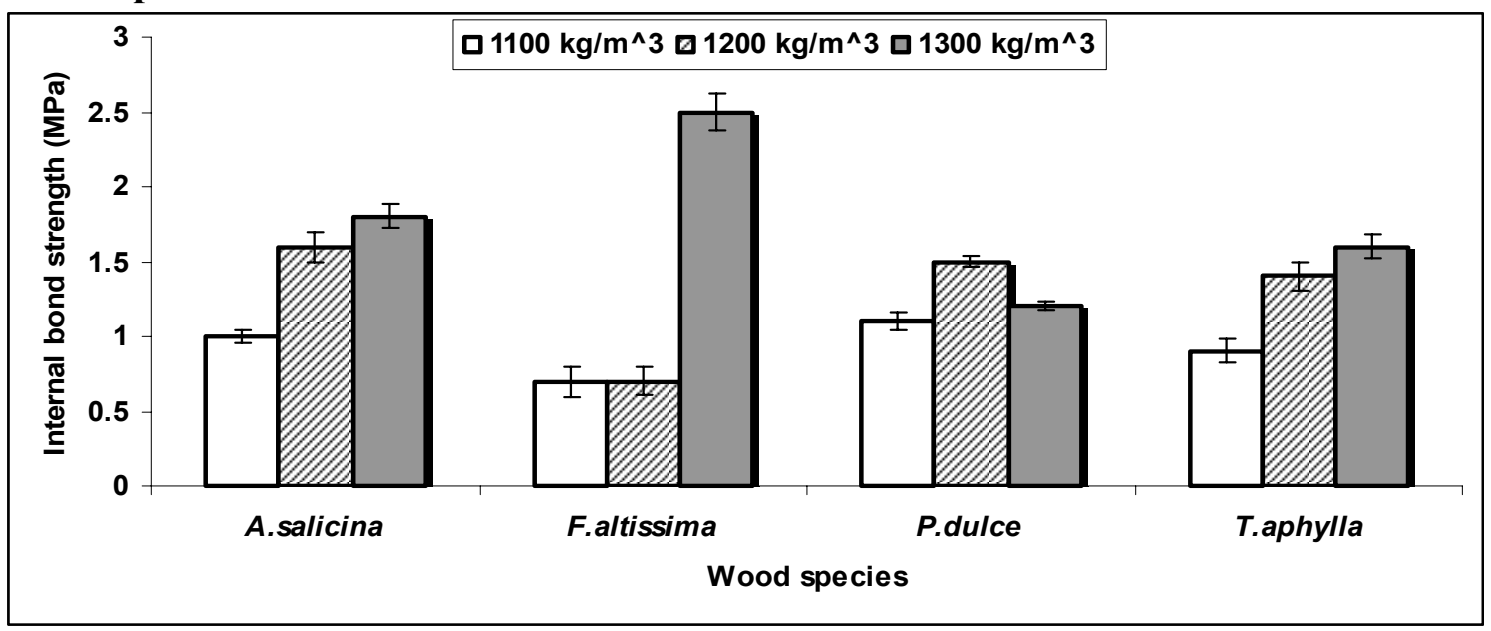

Fig. 5. Internal bond strength of the WCP panels of the four species at the board target density.

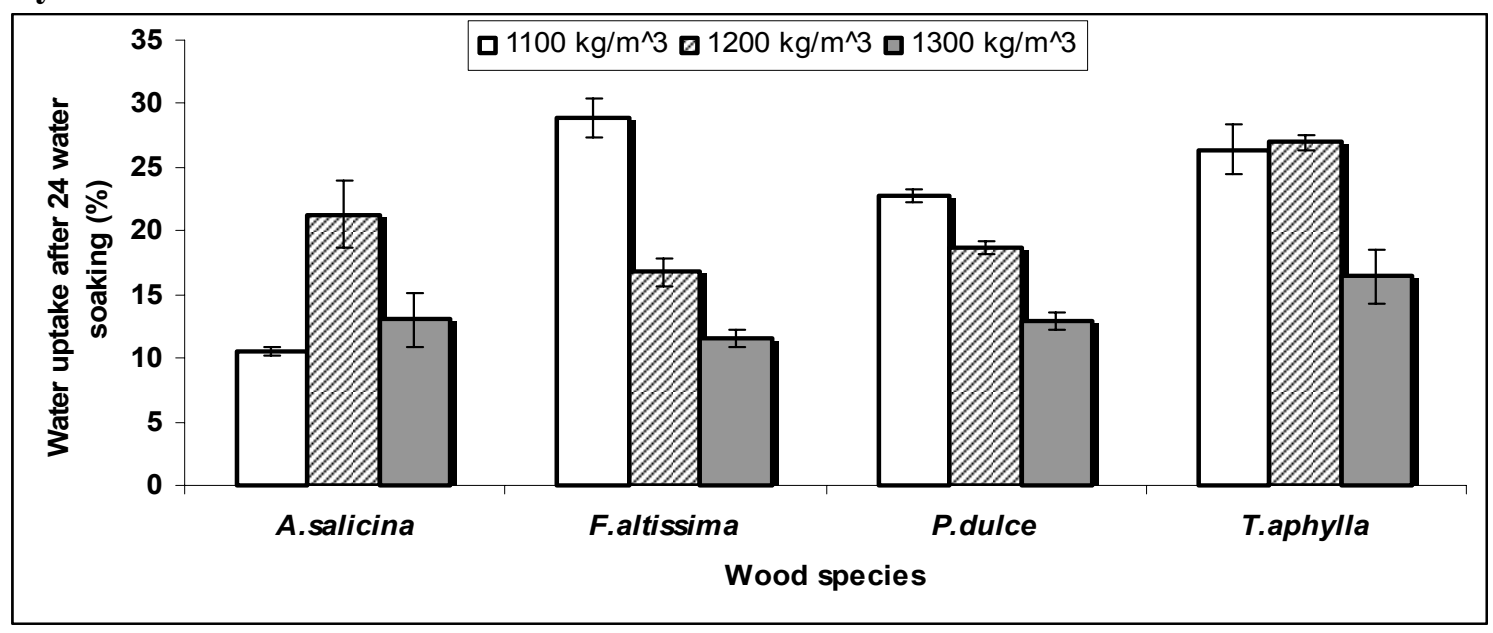

Fig. 6. Water uptake of the WCP panels of the four wood species as affected by the board target density 
The results showed that for each species, the values of the mechanical properties (MOR, MOE, IB, SHP, and $\mathrm{JHN}$ ) increased as the board density increased from 1100 to $1300 \mathrm{~kg} / \mathrm{m}^{3}$. The highest values were recorded for panels from a high board density $\left(1300 \mathrm{~kg} / \mathrm{m}^{3}\right)$, and the lowest value was recorded with panels made from a low board density $\left(1100 \mathrm{~kg} / \mathrm{m}^{3}\right)$. These results agree with the findings by Ajayi and Badejo (2005), which showed that it may be possible to produce stronger, heavier WCP panels by increasing the board density. The mechanical properties of the WCP panels made in this study met the minimum requirements set by the International Organisation for Standardisation (ISO 8335-1987) and compare favourably with data published using different lignocellulosic materials under different manufacturing variables (Semple et al. 2002; Ashori et al. 2011 and Nasser 2014). The results indicated that all the mechanical properties of the WCP panels were directly related to the board target density, as shown in Fig. 3. These results conform with the fact that the density of all types of wood-based panels normally exerts a significant influence over the mechanical properties of the panels and to the previously published studies on cement-bonded particleboards (Badejo, 1988, Ajayi and Badejo 2005, Nasser 2014).

The dimensional stability characteristics of the panels produced from each species increased as the board density of the panels increased from 1100 to 1300 $\mathrm{kg} / \mathrm{m}^{3}$ (Table 7), which can be noted by the decrease in all measured parameters, i.e., water uptake (WU), thickness swelling (TS) and linear expansion (LE) after $24 \mathrm{~h}$ of being soaked in water. These results agree with (Papadopoulos 2008), which attributed these results to the greater volume of material consolidated into the higher-density mat, which resulted in a higher board compaction ratio and consequently, fewer void spaces within the boards. Denser panels, which contain less void spaces in the structure, were expected to absorb less water.

\section{CONCLUSIONS}

Four wood species residues were used in the current work as raw material for CBP panels and could be used to manufacture CBPs after pre-treated by either cold or hot water and by adding either $\mathrm{CaCl}_{2}$ or $\mathrm{MgCl}_{2}$ as an accelerator. Under these conditions, the tree prunings residues of the four wood species are suitable to manufacture high-quality CBP panels. The CBP panels meet the mechanical and dimensional stability requirements of commercial CBP panels. The results indicated that the board density of the CBP panels had a significant effect on the properties of the panels produced. The mechanical properties and dimensional stability characteristics of the panels increased as the board density increased from 1100 to $1300 \mathrm{~kg} / \mathrm{m}^{3}$. To produce CBP panels with good mechanical properties and dimensional stability, a high board density should be used. These tree prunings residues could be used an alternative wood source for cement-bonded particleboards by the wood composite industry.

\section{ACKNOWLEDGEMENTS}

With sincere respect and gratitude, I would like to express deep thanks to NPST program, King Saud University, Saudi Arabia for the financial support (project no 08-ENV 517-02), sponsorship and encouragement. My deep thanks to Dr. Ramadan A. Nasser, Assistant Professor of Forestry and Wood Technology, Faculty of Agriculture, Alexandria University, Alexandria, Egypt for his assistance.

\section{REFERENCES}

Abdel-Aal M.A.; R. A. Nasser and H.A. Al-Mefarrej. 2011. Comparative study on tension and opposite woods of some species grown under Saudi Arabia condition. Middle-East Journal of Scientific Research 7: 490-496.

Aggarwal L.K.; S.P. Agrawal; P.C. Thapliyal and S.R. Karade. 2008. Cement-bonded composite boards with arhar stalks. Cement and Concrete Composites 30: 44-51.

Ajayi B. and S.O. Badejo. 2005. Effects of board density on bending strength and internal bond of cement-bonded flakeboards. Journal of Tropical Forest Science 17: 228234.

Al-Mefarrej H.A. and R.A. Nasser. 2008. Suitability of four lignocellulosic materials in Saudi Arabia for cementbonded particleboard industry and effect of some treatments on their compatibility with Portland cement. Alex. J. Agric. Res., 53: 117-125

Al-Mefarrej H.A.; M.A. Abdel-Aal; R. A. Nasser and N.D. Shetta. 2011. Impact of initial tree spacing and stem height levels on chemical composition of Leucaena leucocephala trees grown in Riyadh region. World Applied Sciences Journal 12: 912-918.

Al-Mefarrej H.A.; M.A. Abdel-Aal and R.A. Nasser. 2013. Chemical evaluation of some lignocellulosic residues for pulp and paper production. American-Eurasian J. Agric. \& Environ. Sci. 13: 498-504.

Almeida R.R.; C. H. del Menezzi and D.E. Teixeira. 2002. Utilization of the coconut shell of babacu (Orbignya sp.) to produce cement-bonded particleboard. Bioresource Technology. 85: 159-163.

American Society for Testing and Materials, ASTM C150-84. 1984. Standard specification for Portland cement. Philadeliphia, Pa. U.S.A. 
American Society for Testing and Materials, ASTM D 1037. 1989. Standard methods of evaluating the properties of wood-base fiber and particle panel materials. Philadelphia, Pa. U.S.A.

American Society for Testing and Materials, ASTM D1102. 1989. Standard Test Method for Ash in Wood. Philadelphia, Pa. U.S.A.

American Society for Testing and Materials, ASTM D1103. 1989. Method of test for alpha-cellulose in wood withdrawn. Philadelphia, Pa. U.S.A.

American Society for Testing and Materials, ASTM D1104. 1989. Method of test for holocellulose in wood.. Philadelphia, Pa. U.S.A.

American Society for Testing and Materials, ASTM D-110584. 1989. Standard test method for preparation of extractive-free wood. Philadelphia, Pa. U.S.A.

American Society for Testing and Materials, ASTM D1106. 1989. Standard test method for acid-insoluble lignin in wood. Philadelphia, Pa. U.S.A.

Aref I.M.; L.I. El-Juhany and S.S. Hegazy. 2003 Comparison of the growth and biomass production of six Acacia species in Riyadh, Saudi Arabia after 4 years of irrigated cultivation. J. Arid Environ., 54: 703-792.

Ashori A.; T. Tabarsa; K. Azizi and R. Mirzabeygi. 2011. Wood-wool cement board using mixture of eucalypt and poplar. Ind. Crops and Prod. 34: 1146-1149.

Badejo S.O. 1988. Effect of flake geometry on properties of cement-bonded particleboard. Wood Science and Technology 22: 357-370.

Cöpür Y.; C. Gular; M. Akgul and C. Tascioglu. 2007. Some chemical properties of hazelnut husk and its suitability for particleboard production. Building and Environment 42: 2568-2572.

El-Juhany L.; I.M. Aref and A.O. El-Wakeel. 2003. Evaluation of using some available lignocellulosic agricultural residues in manufacturing wood-cement boards in Saudi Arabia. A paper presented at the International Conference on Date Palm held at College of Agriculture and Veterinary Medicine, King Saud University (Qaseem Branch), Buraidah, Saudi Arabia, 1619 September, 281-291.

Fengel D. and G. Wegener. 1987. Wood: chemistry, ultrastructure, reaction. Walta de Gruyter. pp: 73.

Fernandez E.C. and V.P. Taja-on. 2000. The use and processing of rice straw in the manufacture of cementbonded fibreboard. In: Proceedings of "Wood-Cement Composites in the Asia-Pacific Region" a workshop held at Canberra, Australia on 10 December, 49-54.

Hachmi M.; A.A. Moslemi and A.G. Camphell. 1990. A new technique to classify the compatibility of wood with cement. Wood Sci. Technol. 24: 345-354.

Hegazy S.S. and I.M. Aref. 2010. Suitability of some fastgrowing trees and date palm fronds for particleboard production. Forest Prod. J., 60: 599-604.
ISO. 1987. International Standards for Cement-bonded particleboards- Board of Portland or equivalent cement reinforced with fibrous wood particles. International Standards Organization, ISO 8335, Switzerland.

Abdel-Aal M.A. 2013. Effect of cooking time, active alkali concentration and refining process on the pulping and papermaking properties of buttonwood residues (Conocarpus erectus L.). World Applied Sciences Journal 27: 1-9.

Miller D.P. and A.A. Moslemi. 1991. Wood-cement composites: species and heartwood-sapwood effects on hydration and tensile strength. Forest Product J., 41: 9-14.

Mohamed T.E. 2004. Effects of mixing some wood and nonwood lignocellulosic materials on the properties of cement and resin bonded particleboard. $\mathrm{PhD}$ thesis, Khartoum University, Sudan.

Moslemi A.A.; J.F. Garacia and A.D. Hofstrand. 1983. Effect of various treatments and additives on wood-portland cement-water systems. Wood and Fiber Science. 15: 165176.

Nasser R.A. 1996. Compatibility of some wood species with portland cement and its enhancement using various treatments and chemical additives. M.Sc. thesis, Department of Forestry and Wood Technology, Faculty of Agriculture, Alexandria University, Egypt.

Nasser R.A. and H.A. Al-Mefarrej. 2011. Midribs of date palm as a raw material for wood-cement composite industry in Saudi Arabia. World Applied Sciences Journal 15: 1651-1658.

Nasser R.A.; H.A. Al-Mefarreg and M.A. Abdel-Aal. 2011. Suitability of vine (Vitis vinifera L.) prunings for woodcement industry. American-Eurasian J. Agric. \& Environ. Sci. 11: 903-910.

Nasser, R.A. 2012. Physical and mechanical properties of three-layer particleboard manufactured from the tree pruning of seven wood species. World Applied Sciences Journal 19 (5): 741-753.

Nasser, R.A. 2014. Influence of board density and wood/cement ratio on the properties of wood-cement composite panels made from date palm fronds and tree prunings of Buttonwood. Alexandria Sci. Exchange J. 35 (2): 133-145.

Okino E.Y.; M.R. de Souza; M.A. Santana; M.V. da Alves; M.E. de Sousa and D.E. Teixeira. 2004. Cement-bonded wood particleboard with a mixture of eucalypt and rubberwood. Cement and Concrete Composites 26: 729734.

Olorunnisola A.O. 2007. Effects of particle geometry and chemical accelerator on strength properties of rattancement composites. African Journal of Science and Technology Science and Engineering Series 8: 22-27.

Olorunnisola A.O. 2008. Effects of pre-treatment of rattan (Laccosperma secundiflorum) on the hydration of Portland cement and the development of a new compatibility index. Cement and Concrete Composites. 30: 37-43. 
Papadopoulos A.N. 2008. Natural durability and performance of hornbeam cement bonded particleboard. Maderas, Clencia y Technological 10: 93-98.

Pehanich J.L.; P.R. Blankenhorn and M.R. Silsbee. 2004. Wood fiber surface treatment level effects on selected mechanical properties of wood fiber-cement composites. Cement and Concrete Research. 34: 59-65.

Roma L.C.; L.S. Martello and H. Savastano. 2008. Evaluation of mechanical, physical and thermal performance of cement-based tiles with vegetable fibers. Construction and Building Materials. 22: 668-674.

Sandermann W. and R. Kohler. 1964. Studies on mineral bonded wood materials VI.A short test of the aptitude of woods for cement bonded materials. Holz. Berlin, 18, 5359.

SAS Institute. 2004. SAS user's guide statistics. Cary, North Carolina, U.S.A.
Semple K.E.; R.B. Cunningham and P.D. Evans.2002. The suitability of five western Australian mallee eucalypt species for wood-cement composites. Ind. Crops Prod., $16,89-100$.

Simatupang M.H. 1979. Der Wasserbedarf bei der Heretellung Zementgebundener Holzspanplatten. Holz. Roh. Werk., 37: 379-382.

Soroushian P.; F. Aouadi; H. Chowdhury; A. Nossoni; G. Sarwar. 2004. Cement-bonded straw board subjected to accelerated processing. Cement and concrete Composites 26: 797-802.

Sudin R. and W.A. Ibrahim. 2001. Cement bonded particleboard from Acacia mangium- A preliminary study. J. Trop. Forest Sci., 2: 267-273.

Vaickelioniene R. and G. Vaickelionis. 2006. Cement hydration in the presence of wood extractives and pozzolan mineral additives. Ceramics Silikaty, 50: 115122.

\title{
الماخص العري

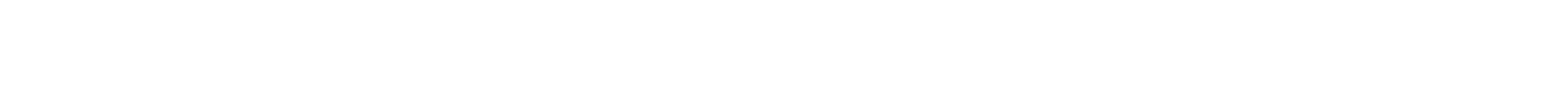

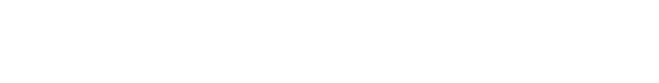

\author{
محمد عبد العل محمد عبد العل
}

البارد أو السلنن وكذلك إضلفة بعض المولن المواد الكيميائية

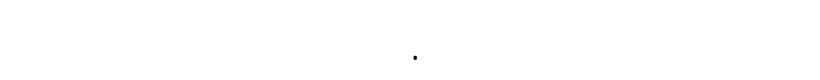

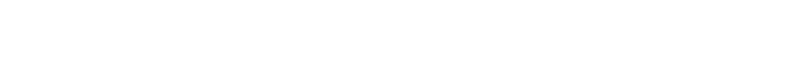

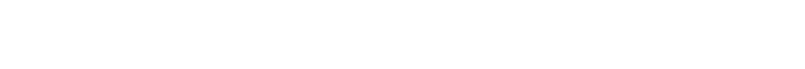

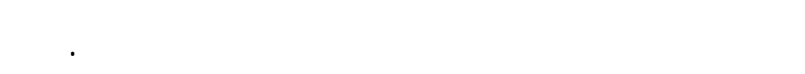

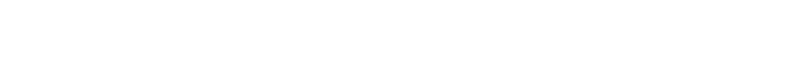

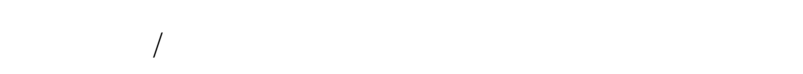
بخواص ميكانيكية جية وثبات بعدي عالي ولذا فانه ينصح بلستخدلمها كمادة خلم في تصنبع الألواح الخشبية الأسمتية.

\section{الكاملت الفتلحية:}

كثافة اللوح، شثب حبيبي لمسمتي، ثبلت بعدي، خواص ميكانيكية، معلملات قبلية، نوالتج نقليم الأشجار، الأنواع الخشبية.
صنمن مشروع ممول من الظطة الوطنية اللعلوم والقنية

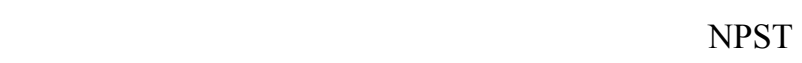

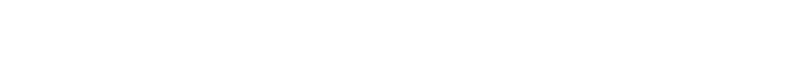
المملكة العربية للسعودية لصناعة الخثب الحبيبي الأسمنتي.

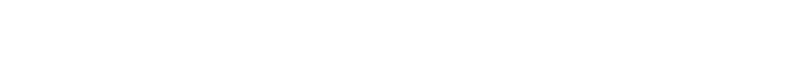

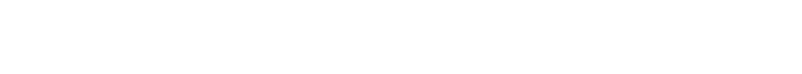
الهشبي المتنج حيث لمتخدمت ثلاث كثافلت للوح الخشبي

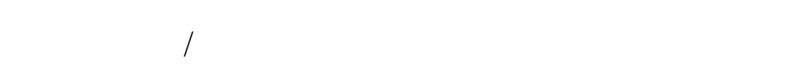

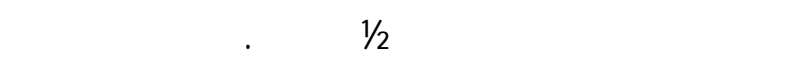
الميكانيكية وخواص الثبات البعدي لالواح الغثب الأسمنتي

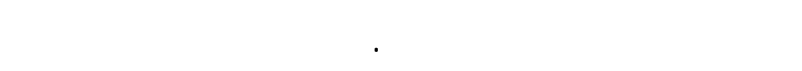

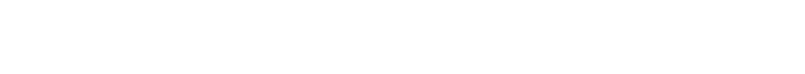
الدرلسة تصلح كمادة خلم لإنتاج الغثب الحبيج الحبيب الأسمنتي وذك بعد لجراء بعض المعلملات القبلية مل القع فى الماء المباء 